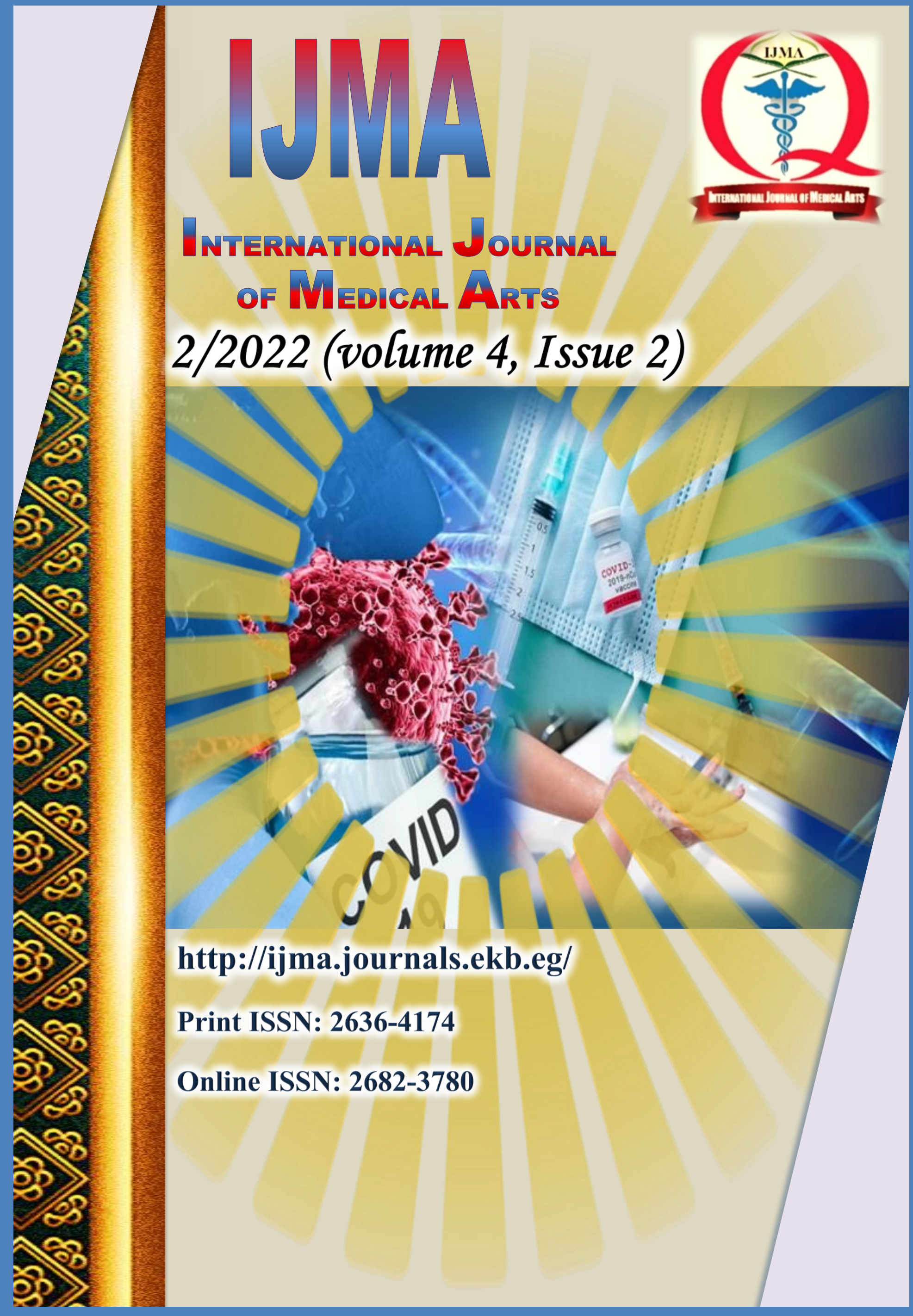





Available online at Journal Website
https://ijma.journals.ekb.eg/
Main Subject [Internal Medicine]

Original Article

\title{
Knowledge, Attitude and Practice of Diabetes Management among Patients with Type II Diabetes
}

\author{
Samah Mohamed Lotfy ${ }^{[1]}$, Monir Hussein Bahgat ${ }^{[2]}$, Mohamed Azmy Khafagy ${ }^{[3]}$, \\ Naglaa Elsayed Abbas * $\left.{ }^{2}\right]$
}

${ }^{1}$ Department of Family medicine, Ministry of Health, Egypt

${ }^{2}$ Department of Internal Medicine, Faculty of Medicine, Mansoura University, Egypt

${ }^{3}$ Department of Public Health and preventive medicine, Faculty of Medicine, Mansoura University, Egypt

\begin{tabular}{|c|c|}
\hline & $\mathbf{A B}$ \\
\hline Article information & $\begin{array}{l}\text { Background: Type } 2 \text { diabetes mellitus }[\mathrm{T} 2 \mathrm{DM}] \text { in Egypt is a fast-growing problem for } \\
\text { health and health care resources. Good knowledge, attitude and practices [KAP] of } \\
\text { DM disease are necessary in the prevention and management of DM. }\end{array}$ \\
\hline \begin{tabular}{l||l} 
Submitted: & $30-09-2021$ \\
Accepted: & $16-10-2022$
\end{tabular} & $\begin{array}{l}\text { The aim of the work: To assess KAP in adult patients with T2DM and correlate it with } \\
\text { socio-demographic factors. And also to evaluate different factors affecting KAP } \\
\text { among the studied population that would help in the development of prevention } \\
\text { programs in Egypt. }\end{array}$ \\
\hline DOI: $10.21608 /$ IJMA.2022.98932.1375 & $\begin{array}{l}\text { Patients and Methods: A total of } 400 \text { T2DM patients attending the endocrinology } \\
\text { department, at the Specialized Medical Hospital, Mansoura University were } \\
\text { interviewed. Questionnaires were completed to determine the demographics and } \\
\text { KAP of the participants about DM. Anthropometric measurements were obtained by }\end{array}$ \\
\hline *Corresponding author & standard techniques. \\
\hline Email: naglaaabass1234@yahoo.com & $\begin{array}{l}\text { Results: The levels of KAP for T2DM disease were poor. Good knowledge, attitude and } \\
\text { practices were among } 35.5 \%, 22 \% \text { and } 49.2 \% \text { of the participants, respectively. A } \\
\text { significant weak positive correlation is detected between knowledge and practice }\end{array}$ \\
\hline $\begin{array}{l}\text { Citation: Lotfy SM, Bahgat MH, } \\
\text { Khafagy MA, Abbas NE. Knowledge, } \\
\text { Attitude and Practice of Diabetes } \\
\text { Management among Patients with } \\
\text { Type II Diabetes. IJMA } 2022 \text { Feb; } 4 \\
\text { [1]: 2102-2111 [DOI: } 10.21608 / \text { IJMA. } \\
\text { 2022.98932.1375]. }\end{array}$ & $\begin{array}{l}\text { housewives, rural residence and negative family history for DM were associated } \\
\text { with poor knowledge. Young participants age }<40 \text { years, less than university } \\
\text { education, and private work were associated with poor attitude. Rural residence and } \\
\text { obesity were associated with poor practice. } \\
\text { Conclusion: The overall level of KAP concerning diabetes is poor. Rural residence is } \\
\text { associated with poor knowledge and poor practice, while obesity is associated with } \\
\text { poor practice. Levels less than university education are associated with poor attitude } \\
\text {.the present study suggests the need of structured educational campaigns with a } \\
\text { prioritized focus on poorer, rural and less educated groups to prevent diabetes and its } \\
\text { complications. }\end{array}$ \\
\hline
\end{tabular}

Keywords: Type 2 diabetes mellitus; Morbidity; Mortality

This is an open-access article registered under the Creative Commons, ShareAlike 4.0 International license [CC BY-SA 4.0] [https://creativecommons.org/licenses/by-sa/4.0/legalcode. 


\section{INTRODUCTION}

Type 2 diabetes mellitus [T2DM] is a global clinical and public health problem. T2DM has very high morbidity and mortality rates. The chronic hyperglycemia of diabetes is associated with various organs failure, especially the eyes, kidneys, nerves, heart, and blood vessels ${ }^{[1]}$. T2DM represent the majority of DM disease burden in Africa, with less than $10 \%$ of DM cases being type $1 \mathrm{DM}^{[2]}$.

The International Diabetes Federation [IDF] listed Egypt among the top 10 countries in the world in the number of patients with diabetes. The prevalence of DM in Egypt has increased rapidly from approximately 4.4 million in 2007 to 7.5 million in 2013. It is expected that this number will jump by 2035 to 13.1 million patient with diabetes ${ }^{[3]}$. Girls are 1.3 to 1.7 times more than boys to develop T2DM during adolescence; it may be related to an increased risk of insulin resistance [IR], as seen in adolescent girls with polycystic ovary syndrome $[\mathrm{PCOS}]^{[4]}$.

Fat tissue is a real endocrine organ with a huge importance in the pathogenesis of IR ${ }^{[5]}$. Obesity has been found to contribute to approximately $55 \%$ of T2DM cases. The increased rate of childhood obesity between the 1960s and 2000s is believed to have led to the increase in T2DM in children and adolescents ${ }^{[6]}$.

Known modifiable risk factors can be reduced and controlled by patients themselves through effective education and enhanced knowledge. Studies from both developed and developing countries have reported that knowledge related to diabetes among patients is generally poor ${ }^{[7]}$. DM proper knowledge can prevent the occurrence of DM complications, which significantly influence their quality of life ${ }^{[8]}$. Patients with diabetes should have positive KAP whose elements are closely related to each other and are dependent on each other. KAP are dependent on socioeconomic background, habits and cultural beliefs ${ }^{[9]}$.

\section{THE AIM OF THE WORK}

The present work aimed to assess KAP in adult patients with T2DM and correlate it with sociodemographic factors. To evaluate different factors affecting KAP among the studied population which will guide to the development of prevention programs in Egypt.

\section{PATIENTS AND METHODS}

This study is a descriptive cross-sectional study with analytic components included 400 patients with T2DM [115 male and 285 female] selected from the Outpatient Clinics of Mansoura University Hospital, Faculty of Medicine, Egypt, from April 2017 to March 2018. Informed consent was obtained from all participants and approval was given by the ethics committee of our institution.
DM was diagnosed according to the American Diabetes Association criteria ${ }^{[10]}$. Patients who were unable to speak, patients with major problem in the hearing, mentally ill patients, pregnant women, and patients with type $1 \mathrm{DM}$ were excluded.

Height and weight were measured to the nearest centimeter and kilogram, respectively and body mass index [BMI] was calculated using the Quetelet Index = body weight $[\mathrm{kg}]$ divided by height squared $\left[\mathrm{m}^{2}\right]^{[11]}$.

Sample size calculation was based on a pilot study that has been carried out on 20 cases before carrying out the study. These 20 cases were excluded from the study. The pilot study illustrates that $45 \%$ has poor knowledge. Using Epi info version 7.2.4.0 to calculate sample size based on $45 \%$ prevalence of poor knowledge, 95\% CI with acceptable margin of error $=5$ then the total sample size was380 and by adding $5 \%$ to compensate for possible attrition then total sample size 400. Sampling was done using simple random sample with all cases that met the inclusion criteria were included until fulfillment of the needed sample size.

\section{Questionnaire}

A structured interviewer-administered questionnaire modified from other related studies was used to collect the data. The first part of the questionnaire covered the respondent's demographic information as: name, age, sex, level of education and occupation.

Knowledge questionnaire composed of 12 questions with 5 questions asking about; causes of type 2 diabetes which have 4 answers, factors that increase the risk of diabetes which have 5 answers, organs affected by diabetes have 4 answers, actions that should be taken in case of hypoglycemia have 3 answers and 7 questions answered as [yes /no] and [correct/incorrect]. Among the 5 previously mentioned questions; every answer is coded as 1 for correct answer and 0 for incorrect; then the total questions coded for knowledge domain is 30. Every correct response is coded as 1 and incorrect as zero and total score for every case was calculated; median score was calculated for all cases and then taken as an arbitrary cut off point with cases have total score of $\leq 13$ will have poor knowledge and cases with total score $>13$ have good score.

Attitude questionnaire is composed of 7 questions each is described as no, yes and not sure and then questions response were combined to be no and yes, no coded as zero and yes coded as 1 [for the first 2 questions the scoring system was reversed]. Median score [6] for all responses was used as an arbitrary cut off point with cases respond to less than or equal to median score is considered poor attitude and more than or equal to median [6] is good attitude.

Practice questionnaire is composed of 10 questions each is evaluated as good practice $=1$ and poor $=0$. Median practice score is 3 that was used as an arbitrary 
cut off point with cases respond to less than or equal to median score is considered poor practice and more than or equal to median [3] is good practice.

\section{Statistical Analysis}

Data were fed to the computer and analyzed using IBM SPSS software package version 22.0. Qualitative data were described using number and percent. Quantitative data were described using mean, standard deviation for normally distributed data and median [range] for non-normally distributed data after testing normality using Kolmogrov-Smirnov test. Significance of the obtained results was judged at the [0.05] level.

\section{RESULTS}

The study included 400 patients with T2DM with a mean age of $52.71 \pm 10.8$ and $58.3 \%$ of the studied sample aged $>50$ years .The majority of the participants were females [71.2\%]. Approximately $52.5 \%$ had intermediate education, $13.2 \%$ with some primary and preparatory school education, $7.2 \%$ had university education and above, and $27 \%$ had no formal schooling. Urban residence present in $51.8 \%$ of the participants and $84.8 \%$ were married. The majority of both men and women were either overweight or obese. The mean \pm SD BMI of the total study subjects was $33.92 \pm 6$. Positive family history of diabetes present in $63.8 \%$ of the studied sample. Oral hypoglycemic drugs were received in $68.8 \%$ of the studied sample for treatment of diabetes as shown in table [1].

Most of the participants were knowledgeable regarding questions asked about the duration of diabetic medications intake [99.8\%], importance of exercise for diabetic patient [98\%], systematic effects of diabetes [94.2\%] and measures taken in case of hypoglycemia [89.8\%]. Most of the participants were unsure about the effect of diabetes on blood vessels $7.2 \%$ [table 2].
The most frequent positive attitude was obtained for periodic consulting doctor for diabetic treatment [99.0] and periodic measuring of blood pressure [92.2]. About $11 \%$ of them felt ashamed suffering from diabetes and $7.0 \%$ of them felt little hope for normal life [table 3].

The highest frequency of correct practice was compliance to take drugs during last week [65.8\%], eating vegetables from 2-3 times per week [49.2\%]. However frequency of exercise, frequent consulting doctor, having examination and laboratory investigations were the least to adopt as shown in table [4].

Poor knowledge, negative attitude and poor practices with regard to diabetes present in a very high percentage of the participants. The median knowledge score was 13, the median attitude score was [6] and the median practice score was [3]. Good knowledge, attitude and practice were among $35.5 \%, 22 \%$ and $49.2 \%$, respectively. A statistically significant weak positive correlation is detected between knowledge and practice $[\mathrm{r}=0.248]$ and between attitude and practice $[\mathrm{r}=0.273]$ as shown in figures [1-3].

Participants aged less than 40 years, housewives, rural residence and negative family history of DM were associated with poor knowledge among the studied group. About $72.8 \%$ of poor knowledge can be predicted by the previous four risk factors. Similarly, young participants aged less than 40 years, less than university education and private work were associated with poor attitude among the studied group. About $78.8 \%$ of poor attitude can be predicted by the previously mentioned risk factors. Rural residence and obesity [grade II and morbid obesity] were associated with poor practice among the studied groups. About $65.8 \%$ of poor practice can be predicted by the previously mentioned risk factors as shown in table [5].

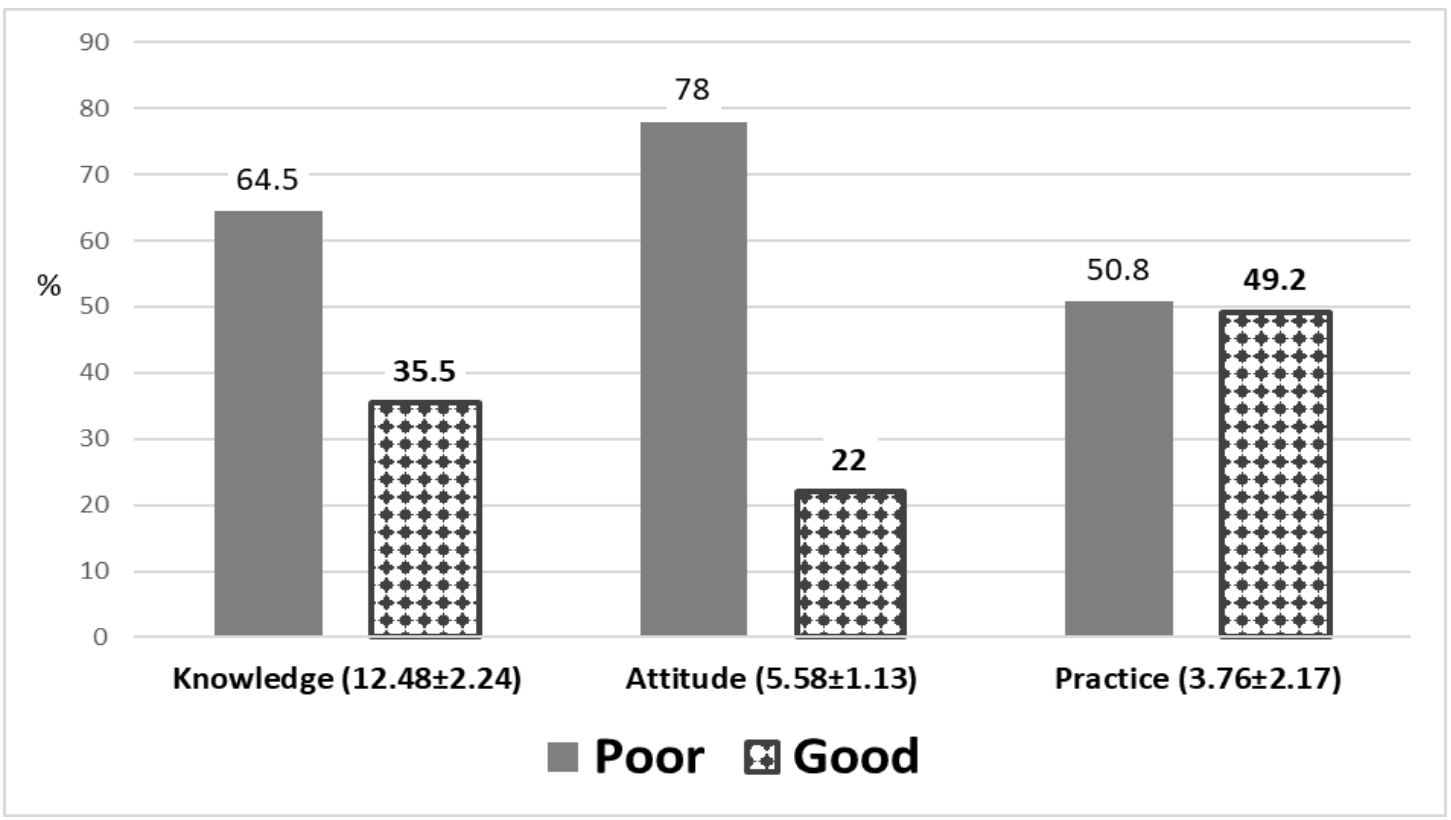

Figure [1]: Knowledge attitude and practice distribution among studied sample 


\begin{tabular}{|c|c|c|c|}
\hline Variables & & Number $[n=400]$ & Percentage \\
\hline Age [years] & $\begin{array}{c}\text { Mean } \pm \text { SD } \\
<40 \\
40-50 \\
>50-60 \\
>60\end{array}$ & $\begin{array}{c}52.71 \pm 10.8 \\
42 \\
125 \\
143 \\
90\end{array}$ & $\begin{array}{l}- \\
10.5 \\
31.2 \\
35.8 \\
22.5\end{array}$ \\
\hline Sex & $\begin{array}{c}\text { Male } \\
\text { Female }\end{array}$ & $\begin{array}{l}115 \\
285\end{array}$ & $\begin{array}{l}28.8 \\
71.2\end{array}$ \\
\hline Educational level & $\begin{array}{c}\text { Do not read and write } \\
\text { Primary \& preparatory Intermediate } \\
\text { education } \\
\text { University education and above }\end{array}$ & $\begin{array}{c}108 \\
53 \\
210 \\
29\end{array}$ & $\begin{array}{c}27.0 \\
13.2 \\
52.5 \\
7.2\end{array}$ \\
\hline Occupation & $\begin{array}{c}\text { Governmental employee } \\
\text { Private work } \\
\text { Manual worker } \\
\text { Housewife } \\
\text { Not working }\end{array}$ & $\begin{array}{c}122 \\
40 \\
33 \\
201 \\
4\end{array}$ & $\begin{array}{c}30.5 \\
10.0 \\
8.2 \\
50.2 \\
1.0\end{array}$ \\
\hline Residence & $\begin{array}{l}\text { Rural } \\
\text { Urban }\end{array}$ & $\begin{array}{l}193 \\
207\end{array}$ & $\begin{array}{l}48.2 \\
51.8\end{array}$ \\
\hline Marital status & $\begin{array}{l}\text { Single } \\
\text { Married } \\
\text { Divorce } \\
\text { Widow }\end{array}$ & $\begin{array}{c}4 \\
339 \\
3 \\
54\end{array}$ & $\begin{array}{c}1.0 \\
84.8 \\
0.8 \\
13.5\end{array}$ \\
\hline BMI $\left[\mathrm{Kg} / \mathrm{m}^{2}\right]$ & $\begin{array}{c}\text { mean } \pm \text { SD } \\
\text { Normal } \\
\text { Overweight } \\
\text { Obese grade I } \\
\text { Obese grade II } \\
\text { Morbidly obese }\end{array}$ & $\begin{array}{c}33.92 \pm 6 \\
15 \\
97 \\
130 \\
93 \\
65\end{array}$ & $\begin{array}{c}- \\
3.8 \\
24.2 \\
32.5 \\
23.2 \\
16.2\end{array}$ \\
\hline Family history of diabetes & $\begin{array}{l}\text { Positive } \\
\text { Negative }\end{array}$ & $\begin{array}{l}255 \\
145\end{array}$ & $\begin{array}{l}63.8 \\
36.2\end{array}$ \\
\hline $\begin{array}{l}\text { Number of family members } \\
\text { suffering from DM }[\mathrm{n}=255]\end{array}$ & $\begin{array}{c}1 \\
2-3 \\
>3\end{array}$ & $\begin{array}{c}144 \\
100 \\
11\end{array}$ & $\begin{array}{c}56.5 \\
39.2 \\
4.3\end{array}$ \\
\hline Treatment taken for diabetes & $\begin{array}{l}\text { Oral hypoglycemic drugs } \\
\text { Insulin }\end{array}$ & $\begin{array}{l}275 \\
125\end{array}$ & $\begin{array}{l}68.8 \\
31.2\end{array}$ \\
\hline
\end{tabular}

Table [2]: Knowledge of the studied sample regarding diabetes

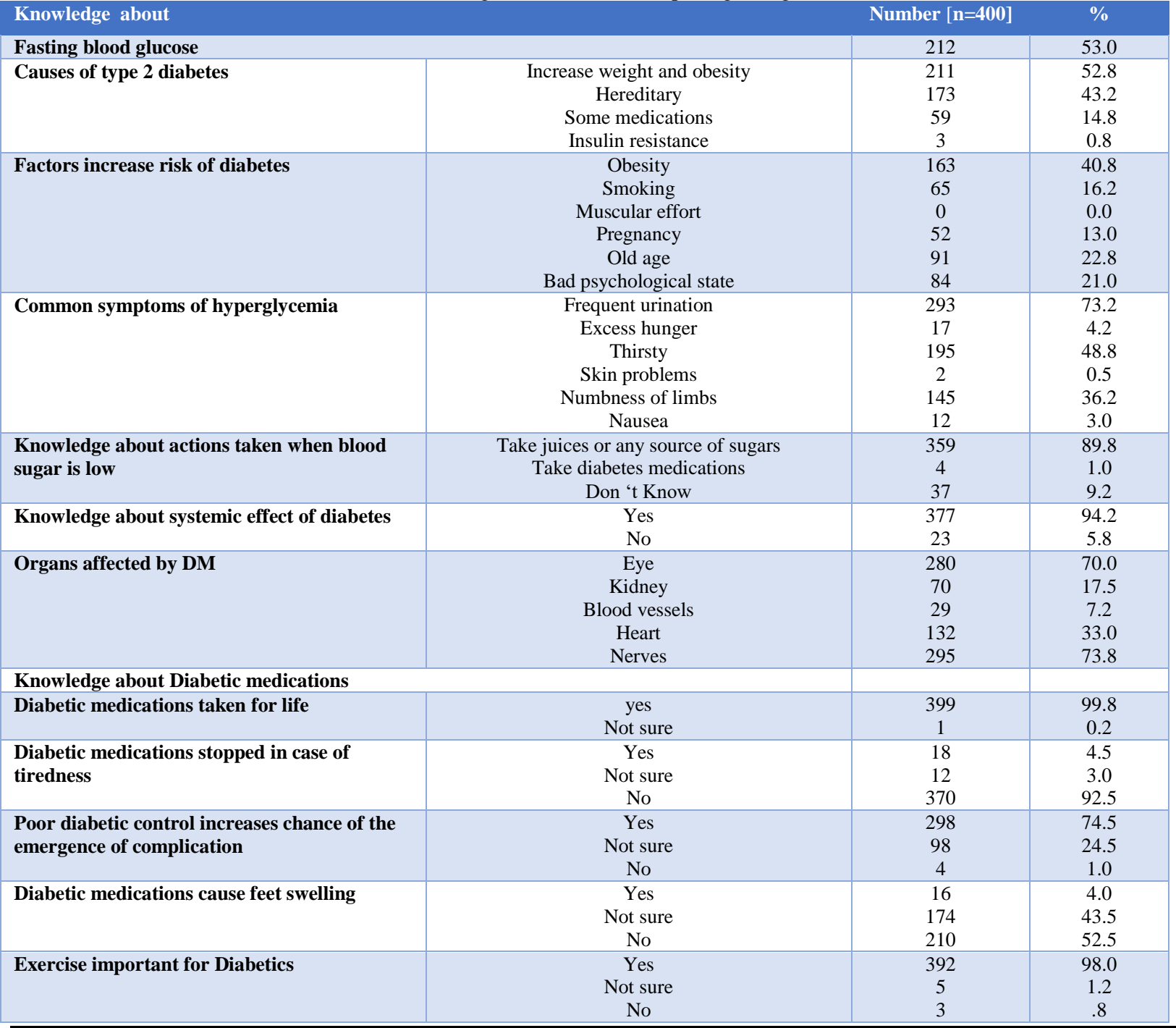


Table [3]: Attitude of the studied sample towards diabetes and regular checkup related to diabetes

\section{Attitude about}

Number $[n=400]$

$\%$

Feeling ashamed suffering from diabetes

\begin{tabular}{|c|c|}
\hline 45 & 11.2 \\
\hline 28 & 7.0 \\
\hline 388 & 97.0 \\
\hline 307 & 76.8 \\
\hline 369 & 92.2 \\
\hline 278 & 69.5 \\
\hline 396 & 99.0 \\
\hline
\end{tabular}

Think that periodic follow up of blood sugar is useful

Think that regular eye examination is useful

Think that periodic measuring of blood pressure is beneficial

Think that referral to more specialized hospitals is important

396

99.0

Table [4]: Practice of the studied sample for diabetic control and regular checkup related to diabetes Practice about $\quad$ Number [n=400]

\begin{tabular}{|c|c|c|c|}
\hline Frequency of eating vegetables & $\begin{array}{c}\text { Daily } \\
\text { 2-3 times/week } \\
\text { Weekly } \\
\text { Irregular }\end{array}$ & $\begin{array}{c}156 \\
197 \\
43 \\
4\end{array}$ & $\begin{array}{c}39.0 \\
49.2 \\
10.8 \\
1.0\end{array}$ \\
\hline Frequency of eating fruits & $\begin{array}{c}\text { Daily } \\
\text { 2-3 times/week } \\
\text { Weekly } \\
\text { Irregular }\end{array}$ & $\begin{array}{c}120 \\
138 \\
135 \\
7\end{array}$ & $\begin{array}{c}30.0 \\
34.5 \\
33.8 \\
1.8\end{array}$ \\
\hline $\begin{array}{l}\text { Frequency of taking medications } \\
\text { during last week }\end{array}$ & $\begin{array}{c}\text { Never forget } \\
\text { Once } \\
\geq 2 \text { times }\end{array}$ & $\begin{array}{c}263 \\
131 \\
6 \\
\end{array}$ & $\begin{array}{c}65.8 \\
32.8 \\
1.5 \\
\end{array}$ \\
\hline Frequency of physical activity & $\begin{array}{l}\text { Daily } \\
\text { 2-3 times/week } \\
\text { Weekly } \\
\text { Irregular }\end{array}$ & $\begin{array}{c}35 \\
64 \\
105 \\
196\end{array}$ & $\begin{array}{c}8.8 \\
16.0 \\
26.2 \\
49.0\end{array}$ \\
\hline $\begin{array}{l}\text { Frequency of consulting the doctor } \\
\text { about diabetes }\end{array}$ & $\begin{array}{c}\text { Monthly } \\
\text { Every3 months } \\
\text { Every } 6 \text { months } \\
\text { When feeling tired } \\
\text { Irregularly }\end{array}$ & $\begin{array}{c}141 \\
103 \\
106 \\
49 \\
1\end{array}$ & $\begin{array}{c}35.2 \\
25.8 \\
26.5 \\
12.2 \\
.2\end{array}$ \\
\hline $\begin{array}{l}\text { Frequency of measuring fasting blood } \\
\text { glucose }\end{array}$ & $\begin{array}{c}\text { Monthly } \\
\text { Every } 3 \text { months } \\
\text { Every } 6 \text { months } \\
\text { Yearly } \\
\text { Upon doctor request } \\
\text { Every } 2 \text { weeks } \\
\text { Every } 3 \text { days } \\
\text { Daily } \\
\text { Weekly }\end{array}$ & $\begin{array}{c}127 \\
96 \\
102 \\
1 \\
69 \\
1 \\
1 \\
1 \\
2\end{array}$ & $\begin{array}{c}31.8 \\
24.0 \\
25.5 \\
.2 \\
17.2 \\
.2 \\
.2 \\
.2 \\
.5\end{array}$ \\
\hline Frequency of measuring $\mathrm{HBA1C}$ & $\begin{array}{c}\text { Every } 3 \text { months } \\
\text { Every } 6 \text { months } \\
\text { Yearly } \\
\text { Upon doctor request } \\
\text { Don't Know } \\
\text { Never do it }\end{array}$ & $\begin{array}{c}38 \\
44 \\
2 \\
202 \\
92 \\
22\end{array}$ & $\begin{array}{c}9.5 \\
11.0 \\
.5 \\
50.5 \\
23.0 \\
5.5\end{array}$ \\
\hline $\begin{array}{l}\text { Frequency of measuring blood } \\
\text { pressure }\end{array}$ & $\begin{array}{c}\text { Monthly } \\
\text { Every } 3 \text { months } \\
\text { Every } 6 \text { months } \\
\text { Yearly } \\
\text { Upon doctor request } \\
\text { When feeling tired } \\
\text { Every } 2 \text { weeks } \\
\text { Weekly }\end{array}$ & $\begin{array}{c}139 \\
100 \\
99 \\
1 \\
55 \\
3 \\
1 \\
2\end{array}$ & $\begin{array}{c}34.8 \\
25.0 \\
24.8 \\
0.2 \\
13.8 \\
0.8 \\
0.2 \\
0.5\end{array}$ \\
\hline $\begin{array}{l}\text { Frequency of having fundus } \\
\text { examination }\end{array}$ & $\begin{array}{c}\text { Monthly } \\
\text { Every } 3 \text { months } \\
\text { Every } 6 \text { months } \\
\text { Yearly } \\
\text { Upon doctor request } \\
\text { Don't Know } \\
\text { When feeling tired } \\
\text { Never do it }\end{array}$ & $\begin{array}{c}7 \\
3 \\
15 \\
25 \\
169 \\
147 \\
2 \\
32\end{array}$ & $\begin{array}{c}1.8 \\
0.8 \\
3.8 \\
6.2 \\
42.2 \\
36.8 \\
0.5 \\
8.0\end{array}$ \\
\hline Frequency of having foot examined & $\begin{array}{c}\text { Monthly } \\
\text { Every } 3 \text { months } \\
\text { Every } 6 \text { months } \\
\text { Yearly } \\
\text { Upon doctor request } \\
\text { Don't Know } \\
\text { Never do it }\end{array}$ & $\begin{array}{c}115 \\
81 \\
66 \\
2 \\
48 \\
74 \\
14\end{array}$ & $\begin{array}{c}28.8 \\
20.2 \\
16.5 \\
.5 \\
12.0 \\
18.5 \\
3.5\end{array}$ \\
\hline
\end{tabular}


Table [5]: predictors of poor knowledge, attitude, and practice among studied sample

\begin{tabular}{|c|c|c|c|c|c|c|}
\hline \multirow[b]{2}{*}{ Predictor $[\mathrm{s}]$} & \multicolumn{2}{|c|}{$\begin{array}{c}\text { Predictors of poor } \\
\text { knowledge }\end{array}$} & \multicolumn{2}{|c|}{$\begin{array}{c}\text { Predictors of poor } \\
\text { attitude }\end{array}$} & \multicolumn{2}{|c|}{$\begin{array}{c}\text { Predictors of poor } \\
\text { practice }\end{array}$} \\
\hline & $P$ value & AOR $[95 \% \mathrm{CI}]$ & $\begin{array}{c}\mathrm{P} \\
\text { value }\end{array}$ & AOR $[95 \% \mathrm{CI}]$ & $\begin{array}{c}\mathrm{P} \\
\text { value }\end{array}$ & AOR $[95 \% \mathrm{CI}]$ \\
\hline $\begin{array}{l}\text { Age/years } \\
<40 \\
40-50 \\
>50-60 \\
>60[\mathrm{r}]\end{array}$ & $\begin{array}{c}0.005^{*} \\
0.36 \\
0.02 *\end{array}$ & $\begin{array}{l}6.34[1.74-23.09] \\
1.59[0.59-4.29] \\
3.14[1.18-8.36] \\
\text { reference group }\end{array}$ & $\begin{array}{c}0.001^{*} \\
0.08 \\
0.18\end{array}$ & $\begin{array}{l}15.66[3.02-81.13] \\
2.03[0.92-4.47] \\
1.63[0.79-3.34] \\
\text { reference group }\end{array}$ & & \\
\hline $\begin{array}{l}\text { Sex } \\
\text { Male [r] } \\
\text { Female }\end{array}$ & 0.45 & $\begin{array}{l}\text { reference group } \\
1.34[0.63-2.84]\end{array}$ & & & 0.83 & $\begin{array}{l}\text { reference group } \\
1.06[0.96-1.36]\end{array}$ \\
\hline $\begin{array}{l}\text { Educational level } \\
\text { Do not read and write } \\
\text { primary \& preparatory } \\
\text { Intermediate education } \\
\text { University education \& } \\
\text { higher [r] }\end{array}$ & $\begin{array}{l}0.19 \\
0.59 \\
0.83\end{array}$ & $\begin{array}{l}2.13[0.68-6.62] \\
1.36[0.44-4.27] \\
1.10[0.45-2.72] \\
\text { reference group }\end{array}$ & $\begin{array}{c}0.01 * \\
0.001^{*} \\
0.03 *\end{array}$ & $\begin{array}{c}4.14[1.28-13.39]^{*} \\
10.69[2.54-45.03]^{*} \\
2.79[1.09-7.15]^{*} \\
\text { reference group }\end{array}$ & & \\
\hline $\begin{array}{l}\text { Occupation } \\
\text { Governmental employee [r] } \\
\text { Private work } \\
\text { Manual worker } \\
\text { Housewife } \\
\text { Not working }\end{array}$ & $\begin{array}{c}0.24 \\
0.41 \\
<0.001 * \\
0.75\end{array}$ & $\begin{array}{l}\text { reference group } \\
1.78[0.69-4.61] \\
1.51[0.56-4.05] \\
3.55[1.78-7.06] \\
0.68[0.06-7.77]\end{array}$ & $\begin{array}{l}0.02 * \\
0.11 \\
0.12 \\
0.92\end{array}$ & $\begin{array}{c}\text { reference group } \\
3.27[1.14-9.36]^{*} \\
2.40[0.82-7.07] \\
1.78[0.86-3.69] \\
0.89[0.11-7.44]\end{array}$ & $\begin{array}{l}0.06 \\
0.15 \\
0.44 \\
0.12\end{array}$ & $\begin{array}{l}\text { reference group } \\
2.41[0.95-6.12] \\
2.04[0.77-5.39] \\
1.26[0.71-2.23] \\
6.73[0.60-75.08]\end{array}$ \\
\hline $\begin{array}{l}\text { Residence } \\
\text { Rural } \\
\text { Urban [r] }\end{array}$ & $0.02 *$ & $\begin{array}{l}1.80[1.09-2.97] \\
\text { reference group }\end{array}$ & & & $0.02 *$ & $\begin{array}{l}1.66[1.06-2.61] \\
\text { reference group }\end{array}$ \\
\hline $\begin{array}{l}\text { Family history of DM } \\
\text { Positive [r] } \\
\text { Negative }\end{array}$ & $0.02 *$ & $\begin{array}{l}\text { reference group } \\
1.82[1.11-2.98]^{*}\end{array}$ & & & & \\
\hline $\begin{array}{l}\text { Marital status } \\
\text { single } \\
\text { married }[\mathbf{r}] \\
\text { divorce } \\
\text { widow }\end{array}$ & & & & & $\begin{array}{l}0.99 \\
0.99 \\
0.99\end{array}$ & Undefined \\
\hline $\begin{array}{l}\text { BMI }[\mathrm{Kg} / \mathrm{m} 2]^{* *} \\
\text { Normal [R] } \\
\text { Overweight } \\
\text { Obese grade I } \\
\text { Obese grade II } \\
\text { Morbidly obese }\end{array}$ & & & & & $\begin{array}{c}0.34 \\
0.33 \\
0.02 * \\
0.004 *\end{array}$ & $\begin{array}{c}\text { reference group } \\
1.80[0.53-6.18] \\
1.81[0.54-6.09] \\
4.88[1.40-16.95]^{*} \\
6.83[1.87-24.99]\end{array}$ \\
\hline Overall percent predicted & & $72.8 \%$ & & $78.8 \%$ & & $65.8 \%$ \\
\hline
\end{tabular}

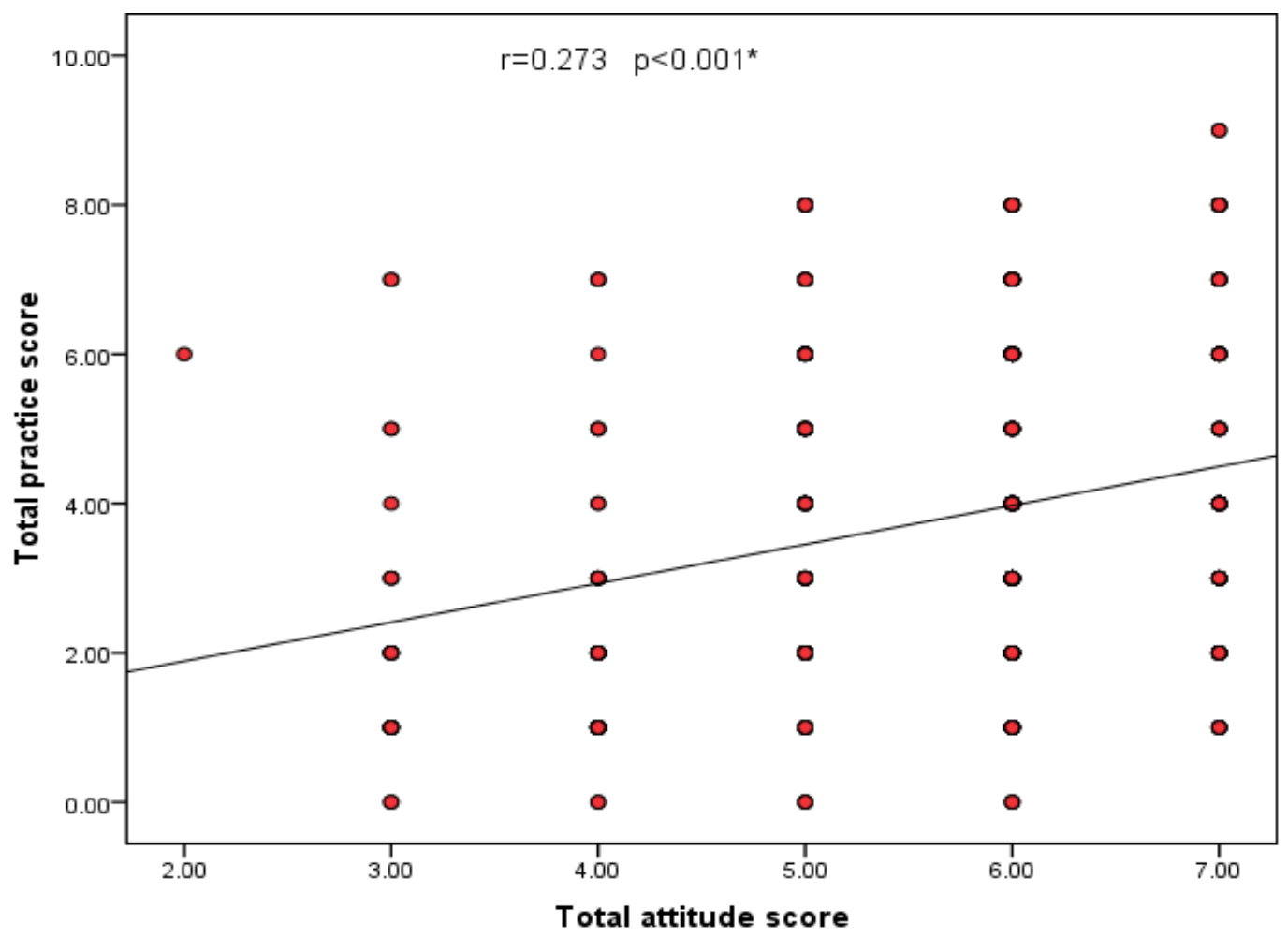

Figures [2]: correlation between attitude and practice among studied sample 


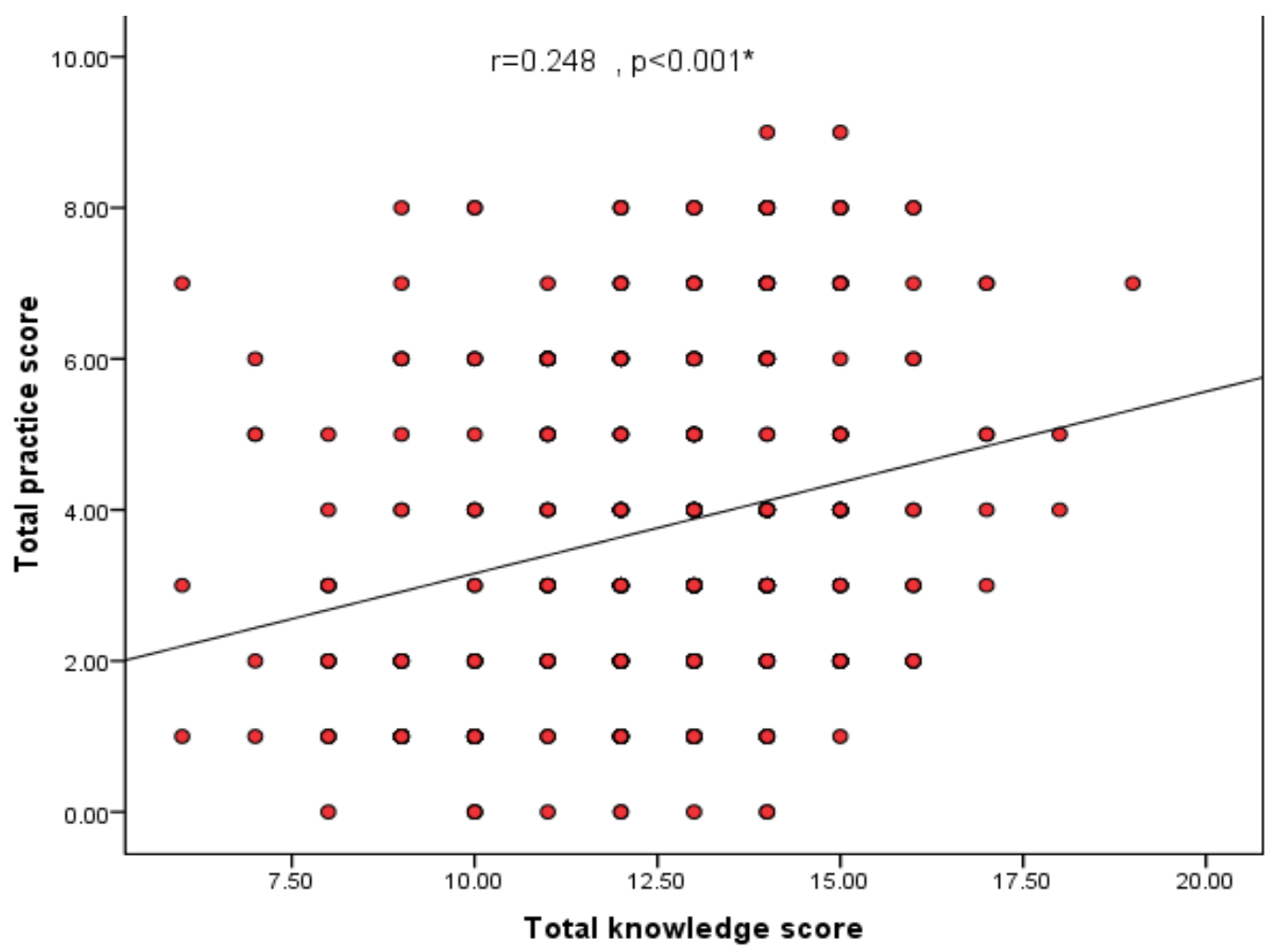

Figures [3]: correlation between knowledge and practice among studied sample

\section{DISCUSSION}

DM plays a vital role in causing morbidity and mortality through its continued clinical consequence. Most patients with diabetes suffer from its complications due to the lack of awareness about it ${ }^{[12]}$.The DM prevalence all over the world has been increasing steadily. In the next decade, the number of people affected by diabetes expected to double due to increase in aging population, thereby adding burden for healthcare providers, especially in poorly developed countries ${ }^{[13]}$.

Better glycemic management in patients with DM requires not only the physician to prescribe an appropriate nutritional and pharmacological regime but also intensive patient education. Studies have shown that patients, who are knowledgeable about the self-care of DM have better long-term control of blood sugar ${ }^{[14]}$. Patient education is the most constructive way that could assist in the early detection, lessen the complications and assist in diabetes management ${ }^{[15]}$. Therefore, good KAP of DM is necessary in the prevention and management of diabetes complications.

In the current study, we aimed to assess KAP in adult patients with T2DM using a structured questionnaire.

The mean age of the participants was 52.71 years, which is near to the result by Gul ${ }^{[16]}$ as the mean age of the participants was $50 \pm 9.32$ years. Also, the study by Shah et al. ${ }^{[17]}$ showed that the mean age of participants was 55 years. Elderly group are vulnerable population, generally suffering from multiple disease and may have compromised self-care activities.

The predominance of females [71.2\%] in the present study agreed with Erasmus et al. and Belsti et al. ${ }^{[18,19]}$ as the majority of the participants in their studies were females. The possible explanation might be due to higher visceral fat in the females than in the men and men tend to be more physically active. This result disagrees with the study carried out by Mekonnen et $\boldsymbol{a l} .^{[20]}$ as the majority of the participants in their study were males.

In the current study, the majority of the participants [64.5\%] had poor knowledge about DM. The low schooling levels of the participants might be a factor that contributed to the poor knowledge. This finding is supported by many studies from both developed and developing countries, which have reported that diabetes knowledge is generally poor among patients with diabetes ${ }^{114,21-23]}$. In contrast, this result disagrees with Mekonnen et al., Asmelash et al. and Alsous et al. ${ }^{[20,24,}$ 25] as $59 \%, 62 \%$ and $53.3 \%$ of the participants, respectively had a good knowledge about DM. The possible explanation might be due to the fact that there are sociodemographic variations across the countries, the difference in health education, sample size and access to sources of information like television, radio and newspaper.

Most of the participants [78\%] had poor attitude to T2DM. The challenges of adhering to a healthier lifestyle and taking medication to prevent complications were contributory factors to negative attitudes among patients with diabetes. This result agrees with Alsous $\boldsymbol{e t}$ al. ${ }^{[25]}$ as $53.7 \%$ of the participants had a poor attitude toward the disease. This result disagrees with Belsti $\boldsymbol{e t}$ al. [19] who stated that about two-thirds of the respondents had good attitude levels. Also, disagrees with the studies done by Mekonnen et al., Rahaman et al. and Assaad Khalil et al. ${ }^{[20,26,27]}$ as 53\%, 66.4\% and $89.3 \%$ of the participants, respectively had a good attitude toward lifestyle modification. The possible explanations for this variation might be due to the difference in health beliefs, demographic characteristics, 
diabetes education programs, cultural differences and the scoring system variation.

Lack of adherence to lifestyle interventions seems to be a common challenge amongst patients with T2DM. Although intensive lifestyle interventions and behavior changes are key components in the T2DM management, the practices related to T2DM in our study was low [50.8\% of the participants had poor practice]. This might be explained by the low income of the patients, as the majority of the patients belonged to the middle socioeconomic class, inadequate health education toward self-care practice and educational level of the study participants. This finding is supported by the studies done by Mekonnen et al. Assaad Khalil et al., Rahaman et al. and Belsti et al. ${ }^{[20,27,26,19]}$ as [59\%$84.7 \%-79.9 \%-51.2 \%$ ] of the participants, respectively had poor practice to DM.

Although the majority of the participants were knowledgeable about the benefits of exercise, only $8.8 \%$ of the participants in this study performed it daily, which is near to the study conducted in Pakistan by Ahmed $\boldsymbol{e t}$ al. [28] as $8.6 \%$ performed exercise daily. The participants' poor practices were also reflected in the high rate of overweight and obesity, which may be resulted from a lack of physical activity and a sedentary lifestyle. People instead of walking tend to make use of public transport and spend a large percentage of their time watching television.

The present study found that young patients age $[<40$ years] associated with poor knowledge and poor attitude to the disease. This suggests that as age increase, individuals become more conscious and aware of their health, and adjust their lifestyle. Also, suggest that younger patients need greater motivation from their family and physician. This finding is supported by Das et al. $^{[29]}$ as he reported that older age group [40-49 years] had better knowledge.

In our study, unemployment was a significant predictor of poor knowledge, as housewives had poor knowledge about DM. This might be explained by that unemployed has low physical activity, have free time to eat more [unhealthy eating habits]. Low income and lack of resources could be a barrier as those who have money could have access to information in different ways. This finding is supported by Asmelash et al. ${ }^{[2]}$ who reported that occupation was significantly associated with knowledge of participants.

The present study found that rural residence was a significant predictor of poor knowledge and poor practice among the studied group. It might be that urban residents had more access to information about life style modification compared to the rural residents through mass media, books and the internet. This is in line with the results by Mekonnen et $\boldsymbol{a l} .^{[20]}$ as urban residents were more knowledgeable.

In our study, less than university education was associated with poor attitude among the studied group. This may be explained by their inability to get enough information through reading from different written documents. Participants who had higher educational status have more awareness about DM. As the level of education increases, the chance of attending different conferences and seminars on DM increase. This coincides with Belsti et $\boldsymbol{a l}$. and Das et al. ${ }^{[19,29]}$ who had found a significant association between higher education and high level of KAP.

In the present study, obesity [grade II and morbid] was associated with poor practice among the studied group. This may be explained by the lack of physical activity and a sedentary lifestyle. As most of them are unemployed and had free time to eat, also they are with low academic status and have low awareness about diabetes self-care.

In the present study, negative family history of DM was a significant predictor of poor knowledge among the studied group. This may be explained by the fact that a positive family history of diabetes had a positive influence on patient's knowledge, as the close relatives with chronic disease may be a good source of health information. This finding is supported by Al-Maskari $\boldsymbol{e t}$ al., Harrison et al. and Ezenwaka et al. ${ }^{[14,30,31]}$.

In the present study there was a significant weak positive correlation between knowledge and practice, as well as between attitude and practice among the studied group. Better knowledge is associated with a better attitude and better attitude is associated with better practice. These findings agree with the findings of other studies as Fatema et al. and Al- Maskari et al. ${ }^{[32,14]}$ who stated that there was a weak, but statistically significant correlation between the level of knowledge and practice and also between attitudes and practice. Also, Asmelash et al. ${ }^{[24]}$ found that knowledge and practice scores of the participants had statically shown a significant positive correlation, in addition, attitude and practice scores showed a positive correlation.

Limitation of the study, female percentage was higher than the percentage of male participants and the two genders data were not analyzed separately. In addition, the findings are based on self-reported data from participants which limits the data validity. As our study was outpatient hospital based, the results may not be truly representative of all DM patients in Egypt

\section{Conclusion}

KAP regarding DM were poor. Lifestyle modification has a great role in the prevention and the control of the disease. DM management depends not only on drug therapy but also on physical exercise, diet and other lifestyle changes. Education plays an important role not only in the prevention of diabetes itself but also in preventing its complication. Younger age group and rural habitats need greater attention in educational campaigns and physicians counseling. 
Recommendation

Conducting awareness program regarding lifestyle modification and diabetes management among diabetic subjects in both clinical and community settings to increase patients' awareness about DM, improve their understanding, compliance and their ability to cope with the disease. Multidisciplinary hospital-based intervention program including a well-trained community doctor, dietician, diabetic nurse and a community-based education program must be applied to improve the KAP of patients regarding their disease.

Financial and Non-financial Relationships and Activities of Interest

None

\section{REFERENCES}

1. Kiberenge MW, Ndegwa ZM, Njenga EW, Muchemi EW. Knowledge, attitude and practices related to diabetes among community members in four provinces in Kenya: a cross-sectional study. Pan Afr Med J. 2010;7:2. PMID: 21918691.

2. Chamnan P, Simmons RK, Forouhi NG, Luben RN, Khaw KT, Wareham NJ, et al. Incidence of type 2 diabetes using proposed $\mathrm{HbA} 1 \mathrm{c}$ diagnostic criteria in the european prospective investigation of cancernorfolk cohort: implications for preventive strategies. Diabetes Care. 2011 Apr;34[4]:950-6. DOI: $10.2337 / \mathrm{dc} 09-2326$.

3. Whiting DR, Guariguata L, Weil C, Shaw J. IDF diabetes atlas: global estimates of the prevalence of diabetes for 2011 and 2030. Diabetes Res Clin Pract. 2011 Dec;94[3]:311-21. DOI: 10.1016/j. diabres.2011.10.029.

4- Taylor R. Type 2 diabetes: etiology and reversibility. Diabetes Care. 2013 Apr;36[4]:1047-55. DOI: 10. 2337/dc12-1805.

5. Eckel RH, Kahn SE, Ferrannini E, Goldfine AB, Nathan DM, Schwartz MW, et al. Obesity and type 2 diabetes: what can be unified and what needs to be individualized? J Clin Endocrinol Metab. 2011 Jun;96[6]:1654-63. DOI: 10.1210/jc.2011-0585.

6. McCarthy MI. Genomics, type 2 diabetes, and obesity. N Engl J Med. 2010 Dec 9;363[24]:2339-50. DOI: 10.1056/NEJMra0906948.

7. Ben Abdelaziz A, Thabet H, Soltane I, Gaha K, Gaha $\mathrm{R}$, Tlili $\mathrm{H}$, et al. Connaissances des patients diabétiques de type 2 sur leur maladie à Sousse [Tunisie] [Knowledge of patients with type 2 diabetes about their condition in Sousse, Tunisia]. East Mediterr Health J. 2007 May-Jun;13[3]:50514. French. PMID: 17687822.

8. Wong MC, Kong AP, So WY, Jiang JY, Chan JC, Griffiths SM. Adherence to oral hypoglycemic agents in 26,782 Chinese patients: a cohort study. J Clin Pharmacol. 2011 Oct;51[10]:1474-82. DOI:
10.1177/0091270010382911.

9. Tahrani AA, Bailey CJ, Del Prato S, Barnett AH. Management of type 2 diabetes: new and future developments in treatment. Lancet. $2011 \mathrm{Jul}$ 9;378[9786]:182-97. DOI: 10.1016/S0140-6736 [11]60207-9.

10. American Diabetes Association. Diagnosis and classification of diabetes mellitus. Diabetes Care. 2014 Jan;37 Suppl 1:S81-90. DOI: 10.2337/dc14S081.

11. Keys A, Fidanza F, Karvonen MJ, Kimura N, Taylor HL. Indices of relative weight and obesity. J Chronic Dis. 1972 Jul 1;25[6]:329-43. DOI: 10.1016/0021-9681[72]90027-6.

12. Wild S, Roglic G, Green A, Sicree R, King H. Global prevalence of diabetes: estimates for the year 2000 and projections for 2030. Diabetes Care. 2004 May;27[5]:1047-53. DOI: 10.2337/diacare. 27.5.1047.

13. Olokoba AB, Obateru OA, Olokoba LB. Type 2 diabetes mellitus: a review of current trends. Oman Med J. 2012 Jul;27[4]:269-73. DOI: 10.5001/omj. 2012.68 .

14. Al-Maskari F, El-Sadig M, Al-Kaabi JM, Afandi B, Nagelkerke N, Yeatts KB. Knowledge, attitude and practices of diabetic patients in the United Arab Emirates. PLoS One. 2013;8[1]:e52857. DOI: 10.1371/journal.pone.0052857.

15. Mazzuca SA, Moorman NH, Wheeler ML, Norton JA, Fineberg NS, Vinicor F, et al. The diabetes education study: a controlled trial of the effects of diabetes patient education. Diabetes Care. 1986 Jan-Feb;9[1]:1-10. DOI: 10.2337/diacare.9.1.1.

16. Gul N. Knowledge, attitudes and practices of type 2 diabetic patients. J Ayub Med Coll Abbottabad. 2010 Jul-Sep;22[3]:128-31. PMID: 22338437.

17. Shah VN, Kamdar PK, Shah N. Assessing the knowledge, attitudes and practice of type 2 diabetes among patients of Saurashtra region, Gujarat. Int J Diabetes Dev Ctries. 2009 Jul;29[3]:118-22. DOI: 10.4103/0973-3930.54288.

18. Erasmus RT, Soita DJ, Hassan MS, Blanco-Blanco E, Vergotine Z, Kegne AP, et al. High prevalence of diabetes mellitus and metabolic syndrome in a South African coloured population: baseline data of a study in Bellville, Cape Town. S Afr Med J. 2012 Oct 8;102[11 Pt 1]:841-4. DOI: 10.7196/samj.5670.

19. Belsti Y, Akalu Y, Animut Y. Attitude, practice and its associated factors towards Diabetes complications among type 2 diabetic patients at Addis Zemen District hospital, Northwest Ethiopia. BMC Public Health. 2020 May 26;20[1]:785. DOI: 10.1186/s12889-020-08953-6.

20. Mekonnen CK, Abate HK, Tegegne ET. Knowledge, Attitude, and Practice Toward Lifestyle Modification Among Diabetes Mellitus Patients Attending the University of Gondar Comprehensive 
Specialized Hospital Northwest, Ethiopia. Diabetes Metab Syndr Obes. 2020 Jun 12;13:1969-1977. DOI: 10.2147/DMSO.S250787.

21. Schramm TK, Gislason GH, Køber L, Rasmussen S, Rasmussen JN, Abildstrøm SZ, et al. Diabetes patients requiring glucose-lowering therapy and nondiabetics with a prior myocardial infarction carry the same cardiovascular risk: a population study of 3.3 million people. Circulation. 2008 Apr 15;117[15]:1945-54. DOI: 10.1161/CIRCULATIONAHA.107.720847.

22. Cho NH, Shaw JE, Karuranga S, Huang Y, da Rocha Fernandes JD, Ohlrogge AW, et al. IDF Diabetes Atlas: Global estimates of diabetes prevalence for 2017 and projections for 2045. Diabetes Res Clin Pract. 2018 Apr;138:271-281. DOI: 10.1016/j. diabres.2018.02.023.

23. Rani PK, Raman R, Subramani S, Perumal G, Kumaramanickavel G, Sharma T. Knowledge of diabetes and diabetic retinopathy among rural populations in India, and the influence of knowledge of diabetic retinopathy on attitude and practice. Rural Remote Health. 2008 JulSep;8[3]:838. PMID: 18656993.20.

24. Asmelash D, Abdu N, Tefera S, Baynes HW, Derbew C. Knowledge, Attitude, and Practice towards Glycemic Control and Its Associated Factors among Diabetes Mellitus Patients. J Diabetes Res. 2019 Apr 8;2019:2593684. DOI: $10.1155 / 2019 / 2593684$.

25. Alsous M, Abdel Jalil M, Odeh M, Al Kurdi R, Alnan M. Public knowledge, attitudes and practices toward diabetes mellitus: A cross-sectional study from Jordan. PLoS One. 2019 Mar 29;14[3]: e0214479. DOI: 10.1371/journal.pone.0214479.

26. Rahaman KS, Majdzadeh R, Holakouie Naieni K, Raza O. Knowledge, Attitude and Practices [KAP] Regarding Chronic Complications of Diabetes among Patients with Type 2 Diabetes in Dhaka. Int J Endocrinol Metab. 2017 Jul 30;15[3]:e12555. DOI: $10.5812 / \mathrm{ijem} .12555$.
27. Assaad Khalil SH, Megallaa MH, Rohoma KH, Ismael $\mathrm{H}$, AbouSeif $\mathrm{M}$, Kharboush $\mathrm{I}$, et al. Prevalence of type 2 diabetes mellitus in a sample of the adult population of Alexandria, Egypt. Diabetes Res Clin Pract. 2018 Oct;144:63-73. DOI: 10.1016/j.diabres.2018.07.025.

28. Ahmed MU, Seriwala HM, Danish SH, Khan AM, Hussain M, Husain M, Ahmed MM, Anis K. Knowledge, Attitude, and Self Care Practices Amongsts Patients WithType 2 Diabetes in Pakistan. Glob J Health Sci. 2015 Nov 3;8[7]:1-8. DOI: $10.5539 /$ gjhs.v8n7p1.

29. Das T, Wallang B, Semwal P, Basu S, Padhi TR, Ali MH. Changing Clinical Presentation, Current Knowledge-Attitude-Practice, and Current Vision Related Quality of Life in Self-Reported Type 2 Diabetes Patients with Retinopathy in Eastern India: The LVPEI Eye and Diabetes Study. J Ophthalmol. 2016;2016:3423814. DOI: 10.1155/ 2016/3423814.

30. Harrison TA, Hindorff LA, Kim H, Wines RC, Bowen DJ, McGrath BB, et al. Family history of diabetes as a potential public health tool. Am J Prev Med. 2003 Feb;24[2]:152-9. DOI: 10.1016/s07493797[02]00588-3.

31. Ezenwaka CE, Offiah NV. Patients' health education and diabetes control in a developing country. Acta Diabetol. 2003 Dec;40[4]:173-5. DOI: 10.1007/ s00592-003-0107-x.

32. Fatema K, Hossain S, Natasha K, Chowdhury HA, Akter J, Khan T, et al. Knowledge attitude and practice regarding diabetes mellitus among Nondiabetic and diabetic study participants in Bangladesh. BMC Public Health. 2017 Apr 26;17[1]:364. DOI: 10.1186/s12889-017-4285-9. 


\section{2) 12022}

international Journal https://ijma.journals.ekb.egl Print ISSN: 2636-4174 Online ISSN: 2682-3780

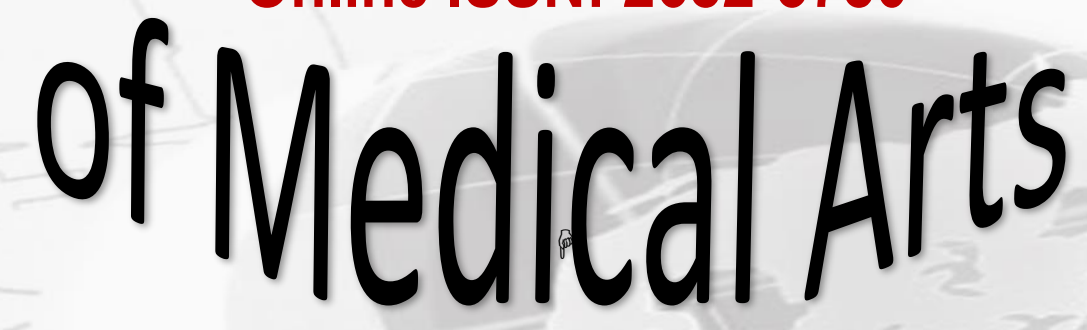

